\title{
The Existence of Local Wisdom Value Through Minangkabau Dance Creation Representation in Present Time
}

\author{
Indrayuda \\ Department of Drama, Dance and Music, Faculty of Languages and Arts, \\ Universitas Negeri Padang, Padang, Indonesia \\ Jln. Prof. Dr. Hamka Air Tawar Padang, Sumatera Barat \\ घE-mail: indrayudayusuf@yahoo.co.id
}

Received: June 9, 2016. Revised: November 12, 2016. Accepted: December 11, 2016

\begin{abstract}
This paper is aiming at revealing the existence of local wisdom values in Minangkabau through the representation of Minangkabau dance creation at present time in West Sumatera. The existence of the dance itself gives impact to the continuation of the existence of local value in West Sumatera. The research method was qualitative which was used to analyze local wisdom values in the present time Minangkabu dance creation representation through the touch of reconstruction and acculturation as the local wisdom continuation. Besides, this study employs multidisciplinary study as the approach of the study by implementing the sociology anthropology of dance and the sociology and anthropology of culture. Object of the research was Minangkabau dance creation in present time, while the data was collected through interview and direct observation, as well as documentation. The data was analyzed by following the technique delivered by Miles and Huberman. Research results showed that Minangkabau dance creation was a reconstruction result of the older traditional dance, and through acculturation which contains local wisdom values. The existence of Mianngkabau dance creation can affect the continuation of local wisdom values in Minangkabau society in West Sumatera. The existence of dance creation has maintained the Minangkabau local wisdom values in present time.
\end{abstract}

Keywords: Minangkabau dance creation; local wisdom values

How to Cite: Indrayuda. (2016). The Existence of Local Wisdom Value Through Minangkabau Dance Creation Representation in Present Time. Harmonia: Journal of Arts Research and Education, 16(2), 143-152. doi:http://dx.doi. org/10.15294/harmonia.v16i2.6146

\section{INTRODUCTION}

Besides for custom retention purposes, the Minangkabau dance is also used for sociocultural, soul expression, cultural characteristic and ideology of Minangkabau tribe manifestation. Therefore, the Minangkabau dance is indirectly bounded with customs' rules, values, and norms of society living in it. Thus, the Minangkabau dance can not be separated from the Minangkabu society's local widom values (Susmiarti, 2009, p. 32).
The society supporting the Minangkabau dance is spread to several kampongs or jorong and nigari. Each nigari has identity and dance style that is different one to another. Based on the old tradition till now, the Minangkabau society in West Sumatera uses Minangkabu dance in custom, sociocultural, and entertainment industry events and activities. Usually, people coming from the city part of West Sumatera also use the Minangkabau dance for complementary entertainment in an official hospitable event, private party as 
well as custom ritual.

Recently, globalization and information technology have penetrated through various sectors within the society's life., both in the countryside or the city, and one of it is in the sector of art and tourism. Globalization has bought an impact to the presence of the entertainment industry and tourism in Indonesia in general and in West Sumatera in particular. The emerging of the entertainment industry, has pushed the formation of various event organizers and dance studios that emerges like mushrooms in Kota Padang and Bukittinggi as well as Padang Panjang and other cities in West Sumatera. By the presence of entertainment industry growth in some big cities in West Sumatera, it affects to the emergence of various new dance creation works. The new dance creations are creative products created by dance artists and creators from West Sumatera that are rooted from Minangkabau traditional dance.

As stated by Iriani $(2014$, p. 47) in her research results, recent Minangkabau dance creation is a trend in the society to be used for various ceremonial and entertainment events, in the area of tourism, private, and public entertainment. The popular Minangkabau dance told in this context is a new creation of Minangkabau dance, resulted from both modification and acculturation. This new dance is a representation of culture and customs of Minangkabau that expresses local wisdom.

Darmawati in her research entitled "Transformation of Galombang Duo Baleh Dance in Sintuak Society" (2014) explains that there is a change on the presentation form of Gelombang Duo Baleh dance from symbolic to represent. It means that the representative presentation of the dance has attempted to repromote local values in the Gelombang Duo Baleh dance.

In line with this study, a research about the Existence of Indang Dance in the Territory of Kanagarian Pincuran Sonsang by Indrayuda (2014) found that Indang Dance as dance creation which was popularized in the nagari (village) area of Pincuran Sonsang by an academic artist does not meet any challenge coming from the local people. In addition to this, the fact shows that Indang dance can be accepted by people in nagari Pincuran Sonsang as a new culture, even though people have already had the previous Indang dance that has become their inherited culture for a very long time. The reasons towards the acceptance was because the Indang dance is representation of local wisdom which visually describes local wisdoms of Nagari Pincuran Sonsang society.

Since the performing art industry is encouraged in West Sumatera, there is a form of development on Minangkabau dance from the perspective of motive, floor design, musical design, as well as costume design and its performance procedures. This quality development also let to the quantity development. It means that amount of Minangkau dance increase along with the increasing number of the dance distribution. The form development has made the custom elite to feel restless, as well as the local artists from nagari and kampong. Both the elite and local artists feel terrified that one day the traditional Minangkabau dance will be left behind by the supporting society. Recently, the fact shows that individual and academic artists have preserved Minangkabau traditional dance through dance creation as the source of their works.

Virginia (2015, p. 56) in her study about "The existence of Women in Pasambahan Syofiani Dance" explains that Pasambahan Syofiani dance is a form of Pasambahan dance that has been acculturated with Galombang dance, a Minangkabau traditional dance with Malay dance style. Through the dance work of Galombang dance creation, Syofiani represents the characteristic of the actual Minangkabau women. The illustration of character and behavior of Minangkabau women is expressed through movement acculturation in Malay dance style, so that the personal values of Minangkabau women are emerged in the dance. The existence of $\mathrm{Pa}-$ sambahan dance in Syofiani version is resulted from the widespread of market de- 
mand on entertainment industry in West Sumatera recently.

The reality shows that with the improvement of the entertainment industry, new forms of recent Minangkabau dance creation have emerged. The creation of Minangkabu dance is a reconstruction form of the old version of Minangkabau dance, so that with the transformation, the Minangkabau dance will always exist within the society life (Susmiarti, 2014, p. 72). This is in line with the old philosophy of Minangkabau customs "ancak-ancak dipabarui, kain dipakai usang adat dipakai baru". It means that the development of the old (traditional) dance reconstruction with the process of creativity has developed quality and indirectly have preserved the existence of Minangkabau dance in the life of its society.

According to this reality, the development still shifts the position of custom values and Minangkabau culture in the new valuable forms that are not relevant with the Minangkabau customs. Since the development is in line with the Minangkabau philosophy "walaupun bakisa, tapi tetap bakisa di lapiak nan salai". It means that even though it is developed, but the development is still made based on its original form and is not far from the initial track.

According to Wahyuni (2015, p. 97), performing art in Minangkabau is the manifestation of local wisdom values that is obeyed by the Minangkabau society. It means that the art, like music and dance, is a representation of local wisdom values owned by Minangkabau tribes. Therefore, art like dance is a medium, the place of continuation and learning media of local wisdom values in Minangkabau.

In line with the statement, Asni (2014, p. 32) states that local wisdom is valued or ideology that is a view of life and life guidance that reflects the characteristic of a nation. Thus, in Minangkabau, local wisdoms are inherited and culturalized from the ancient times. The local wisdom is inherited and taught in many ways, one of it is by inserting the element of the arts. Essentially, the Minangkabau traditional arts, as Galombang and Pasambahan and also other dances are media to deliver local wisdom values to the society.

Hanefi (2011, p. 11) states that art, like music and dance, are part of the culture of a society, and also an expression of a life reality. Therefore, dance and music, from the anthropological perspective, are products of human behavior that relates to the social and cultural lives of the supporting society. Because of this, arts like music and dance in Minangkabau considered as a means to express message of the existing local cultural values. Even, if one day the dance and music of Minangkabau culture has been transformed into a new form, but, as long as those dances and musics are still rooted in the manifestation of tradition, then the cultural values and local wisdom in it will still exist in line with the continuation of the art.

Issues dealing with the local wisdom, values are essential factors to be analyzed in a study, considering the tendency of the dance creation work of Minangkabau in present time is oriented mostly on local values. The tendency of the artist working on the dance creation gives impact to the preservation and values included within the work.

It considers important to analyze how the existence of local wisdom, values in the recent Minangkabau dance creation, considering that the tendency of people is still intensively using the Minangkabau dance creation in various events and ceremonial activities in West Sumatera, even though the globalization stream affects the thought pattern of West Sumatera nowadays. In its time, this dance creation is one of representation medium that needs to be analyzed as a means to make local wisdom values exist. Previous researches had given us a picture that the existence of dance creation is one of representation form of Minangkabau culture and customs, so that the customs and culture can be communicated to the society in a more modern form. Based on the previous research, it can be inferred that the problem, according to the existence of dance creati- 
on needs to be analyzed deeper, especially in its relation to the implication of the dance to the Minangkabau local wisdom values for the anticipation of the possibility value extinction in modern life, especially in West Sumatera.

An art form, like the Minangkabau dance, is a publication medium and expression of the cultural values that exists in the owner's society's life. Because of that, through Minangkabau dance creation in present time, the creative artists started to re-represent the values. The impact of the representation is predicted to be able to become a preservation medium towards the existence of Minangkabau local wisdom values, both for the present and future societies.

Referring to the phenomenon of the existence of dance creation recently, and seeing the intensive symptoms of society on using the dance creation, the dance creation becomes popular in the society nowadays. One of the reasons of the art acceptance and the popularity of the dance creation in the society is the cultural identity similarity for Minangkabau society. Therefore, society values the dance creation's values as an art bringing the identity of the society.

Based on the reality, thus, this study is aimed at revealing and explaining the role of Minangkabau dance creation as a medium to keep the existence and continuation of local wisdom values in the life of present Minangkabau society.

\section{METHOD}

This study is a qualitative research employing descriptive method. In qualitative way, the research question will be revealed in its relation to the existence of Minangkabau local wisdom values and to the existence of present Minangkabau dance creation in West Sumatera.

The subject of the research was Minangkabau dance creation that focuses on the local wisdom, values that is existed in the dance creation where it refers to. All matters related to the local wisdom, values in Minangkabau dance creation are made into the study object of this study. Informants for this study are the actors and creators of dance creation, artists, part of custom elite as well as the society, the consumers and managers of the dance creation, community leaders, and government that is related to the existence of the arts in West Sumatera. All interviews are recorded both in written and in audio-visual.

Data was collected through observation, interview, literary study, and documentation study related to Minangkabau dance creation and local wisdom. Further, the study analysis is done by employing the method by Miles and Huberman by collecting data, reducing data, and verifying the data so that the data can be interpreted by inferring the results to the research questions which is related to the existence of local wisdom values through Minangkabau dance creation work.

\section{RESULTS AND DISCUSSION}

Based on the research results, it is found that most of the traditional-oriented dance creations are spread out in cities and regencies around West Sumatera, i.e. Kota Padang, Bukit Tinggi, Payakumbuh, Sawahlunto, Pariaman, Padangpanjang, and in Southern coastal regency, Solok, South Solok, Padang Pariaman, Sijunjung, Agam, and Dharmasraya.

The Minangkabau dance creations which are spread out in the cities and regencies throughout West Sumatera is a dance creation that consists of two concepts of formations and creations. The first is an acculturation result and the second is the reconstruction result. The two structural concepts produce the new Minangkabau dance creation formation that is oriented on the old traditional dances.

The dance creation that is oriented in the older and the more traditional dance are the Piring dance, Indang dance, and Galombang. These three dances creations are emerging on various version spread out in may cities and regencies in West Sumatera. Each region and city in West 
Sumatera have many versions about New Creation of Piring Dance, New Creation of Galombang Dance, and New Creation of Indang Dance.

The three forms of dance creation are New Creation Piring Dance, New Creation Galombang Dance, and New Creation Indang Dance that are kinds of dance that is usually shown in kinds of cultural events and festival, contests, and in various of activities or ceremony both for customs or government purposes.

In line with this, the three forms of Minangkabau Dance creation are also used by dance studios and dance schools and academies as learning materials.



Figure 1. Traditional and Creational Piring Dance Rooted from The Traditional Piring Dance

The new dance creation forms which are produced by art studios and art schools or art academies in West Sumatera are various. From the variety of forms, the local values of Minangkabau are still attached. In other words, those dance creations are oriented to the local values that are expressed through new innovative package of dance.

As stated by interviewee 1 on April 25,2015 that the development of dance creation in West Sumatera especially in Kota Padang, the development of dance creation was getting faster in early 2000s. The form of dance creation is created based on various concepts and appearance forms, as well as the work orientations. One that is usually used by the city people in government occasion and custom occasion are dance creations from Minangkabau that are tradition-oriented. In half of exclusive hotels, in addition, the Minangkabau dance has been widely used as well. The concepts of work are also varied, started from reconstruction, acculturation, modification, and innovative creation as a result of the advantageous results of a photographer's imagination.

Based on the researcher's observation, there are five forms of dance creation from the category of creative concept. The five concepts of arrangement and creation are, (1) reconstruction, (2) modification, (3) acculturation, (4) transplantation, and (5) invention. These five forms of creation are used by the Western Sumatera choreographer

Minangkabau dance creation in present time has contributed to the influence distribution of Minangkabau cultural value to the society in West Sumatera. Through various kinds of dance creation that is used by society recent days, indirectly, it has impacted the Minangkabau local wisdom value preservation. Society uses the dance creation for middle to upper class people of Minangkabau that usually live in a modern style that has been given with an understanding of local wisdom values through the dance creation performance. In their turns, gradually but surely, the society can understand and practice the Minangkabau local values in their life, although the quality is not like the fanatical society's one.

Based on the research findings in the field, several local value wisdoms are found to be included in the present time's Minangkabau dance creation. Among 
them is the value of togetherness, the value of respecting one's existence, the value of honest and discipline, the value of interaction ettiques and integration, like, sadanciang bak basi saciok bak ayam (that is one voice in togetherness), the value of solidarity, the value of empathy and sympathy, as well as the value of strength and courageous.


Figure 2. Dance Creation Reconstruction Product of Piring Dance. (Documentation from Research Team of Sendratasik FBS UNP 2015)

Besides the value described in the previous part, there is also the value of responsible, harmony, balance, tolerance, and appreciation is found. All the values of local wisdom can be sorted one by one on Minangkabau dance creation, especially on the dance creation which the work is monumental.

This kind of artwork like one in Minangkabau dance creation is an informa- tion resource of local wisdom values. As stated by Widiyono (2013, p. 31), an artwork is one of information sources about behavior, values, and typical dreams of the members of every layer of society to the certain family group or certain generation. An artwork is an artistic work that is formed from a process of imagination and objective reality process. The artwork is an artistic work that is formed through a process of imagination and process of objective reality. Artwork likes literature or performing art is usually created related to the problems or events that happened in the society where the artists live and stay that is related to the experience that is owned by the society. Therefore, artist of dance creation of West Sumatera in present time manages dance creation not far from the knowledge and appreciation towards the value of local wisdom that they have. This fact causes the Minangkabau dance creation to be an agent for the preservation of Minangkabau local wisdom values that is affected to the continuation of the values in present Minangkabau society in West Sumatera.

Based on an interview with interviewee 2 on April, 17 ${ }^{\text {th }}$ 2015, there is known that the values of local wisdom in the Galombang Kreasi dance are actually a reflection of Minangkabau people's personality who like to respect guests, or in Minangkabau philosophy meaning putiah kapeh dapek di like, putiah hati bakaadaan. It means that with all his pleasure, as a host, one should welcome the guests open handed to the event the host held. As a symbol of honor and happiness to the coming of a guest, a host presents Galombang dance as a representation and reflection of the expression of happiness and honored. The local wisdom values can be taken from Galombang dance performance, there are: the value of respect that is reflected from the movement of worshipping, the value of protection for the people visiting the host which is looked from the movement of waving hands and standing in line to welcome people coming to the event of ceremony. The form of protection in welcoming guests is by 
giving the guests an umbrella as part of performance structure of the Galombang Kreasi dance.

Adding the interviews done by the two previous interviewees, an interview on April 25 $5^{\text {th }}, 2016$ states that the local wisdom, values can be interpreted from the Galombang Kreasi dance about the existence of the value of politeness, being open to others' presence, sincere in receiving other's presence, as well as the feeling of protection, and responsible.

Both of the dance experts interviewed as interviewee 3 and 4 were senior choreographers from Minangkabau West Sumatera. They explain that Galombang Kreasi is part of reflection of local wisdom values, that implicit in the form of the dance performance or work. The local wisdom is a special characteristic that has been inherited and had by all layers of society in Minangkabau. The role done by this dance creation in present time is as a medium to deliver or the learning media. Although part of the message in the local wisdom values is rarely responded by most of society in West Sumatera recent days. Since the society has been captivated by the element of entertainment of an artistic and aesthetic dance creation, meanwhile the audiences or society has forgotten to understand that inside the dance is a message from the Minangkabau local wisdom values.

In addition to this is explained by interviewee 5 in his interview on April, $26^{\text {th }}$ 2015. He explains that dance creation refers to the traditional dance that contains plenty of local wisdom values that happen to be learning media for character learning of Minangkabau society. Since in past time, dance is used as learning media that is implemented while playing, the most important is to get a lesson from the art performance. Because of that, to the Minangkabau dance creation, there are also found some local wisdom values, such as the value of cautious, discipline, tolerance, politeness, order, solidarity and responsible, as well as courage. According to one of the interviewees, that one of the reasons that dance creation is accepted by the society is because inside the dance, the Minangkabau local wisdom values are existed. The reason causes the dance creation to be cultivated by people of Minangkabau in West Sumatera these days. Because of the cultural identity reason, it causes the dance creation to be popular in the middle of the city and rural people throughout West Sumatera in recent times. The reality shows that the Indang dance and the new creation of Piring dance becomes a choice for public to celebrate sociocultural events and even the custom ceremonial activities.

Thomas (2014, p. 30-31) states that as a cultural revitalization case in Lampung, through the new tradition that is repackaged to be a medium for local value preservation. The local value can keep continued by packaging it into a new form, so that the society can keep enjoying and understanding the local values. In its turn, the local values will keep its actualization if it is packaged in a new form based on the present society's taste.

In relation to what has been said by interviewee 5 before, recently in West Sumatera, the local artist has packaged an innovative dance creation without leaving the local values off of their culture. Visually, the new dance is more interesting and artistic compared to the traditional dance that they have, but from the content perspective, the dance does not leave their local wisdom values. Through the collaboration between new form and traditional cultural values existed in the society's neighborhood, then the Minangkabau dance creation is called as a publicity medium of Minangkabau local wisdom values. Through the dance creation in West Sumatera recently, the influence distribution of local values has affected the cultural and well-mannered livelihood within the Minangkabau society.

Ardipal $(2015$, p. 17) states that recently in West Sumatera, there are the emergence of new artists who oriented mostly on the traditional arts. Artists start to use traditional art material to form a new work which is more popular. This is done to fulfill the taste of both local and 
international societies, so that, although a new form of style and local color still can be seen from the work, thus the new music and dance will not be apart from the local society identity. This strategy is used by the artists to attract the sympathy of local audience.

The cultural phenomenon that was seen and described by Ardipal is the attitude of the artist in deciding the cultural strategy of a local artist to their art work marketing. However, behind that, the strategy has triggered an advantage for the preservation and continuation of the Minangkabau local wisdom values. Although the dance is created by an innovative new pattern of dance, but the dance is still keeping the content of messages related to the local wisdom values. As a result, the dance work can be accepted and understood by the society of West Sumatera. The impact of this artist's strategy causes the Minangkabau local wisdom values to keep remained and continued for future life.

Murniati (2015, p. 27) explains that the tendency of the performing art artists in West Sumatera recently is oriented on the local wisdom and collaborated its work to be more modern. The target of the performing art products is to maintain the local values, and influence the audience's thought through the modern taste that is created. It means that physically the material shown is new but contains local things and values, so that the performing art still can be accepted, but influenced the imagination of audiences as if they are living inside the identity.

In line with that, Opsantini (2014, p. 3) states that the arts which were oriented by traditional culture will never ne aparted from the traditional values. The traditional values that is existed within the artwork become the identity of the work, deciding whether the work has emphasized the religious value or social value of the society. Those values are shown is that the artwork will be considered as the supporting society's representation.

As also explained by Wadiyo (2015, p. 151) that art can build the values existed in the society, such as the value of religion or education. Arts, like music and dance can build mental and spiritual, naturally. It means that the values within the arts can affect human, then the impact of the arts is felt through the understanding of human towards values, like all what local wisdom values sontained in the dance creation, as local wisdom values contain in Minangkabau dance creation local wisdom values. The reality of Minangkabau dance activity in present time shows that the dance has turned to be the agent of local wisdom values and has affected the preservation and continuation of those values in the life of society in Minangkabau West Sumatera both in present and future time.

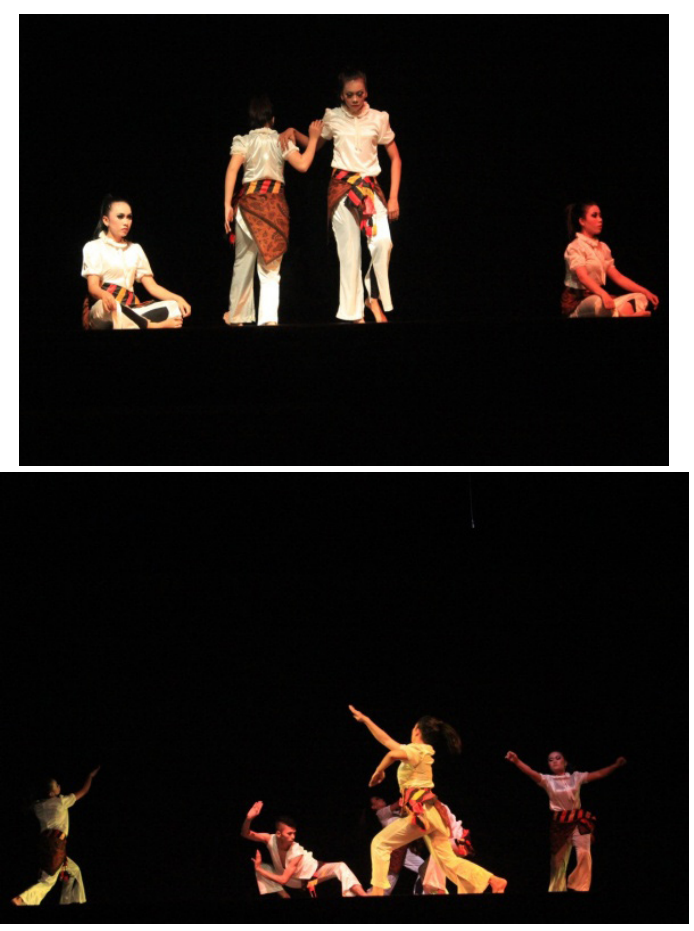

Figure 3. Dance Creation Containing Local Wisdom Values in Contemporary Art Work (Documentation of Sendratasik Research Team, 2015)

\section{CONCLUSION}

Minangkabau Dance Creation has experienced acculturation and has been arranged in the form of reconstruction. Even though the dance creation is created in various ways, however, the dance essentially contains local wisdom values in its 
performance and art work. In fact, almost every week, the dance creation of Minangkabau Galombang dance is performed at the wedding reception in many big cities around West Sumatera. Besides Galombang dance, there is also the dance creation of Piring dance that is also performed in many parts of West Sumatera.

Another reality is the tendency of Minangkabau society recently that employs more modern life rather than the old traditional lifestyle, but the context is still bounded with the local wisdom values of their environment. As a result, the change found in Minangkabau dance creation is limited only to the visual or formation, but the content still reflects and illustrates the cultural identity of Minangkabau society through the local wisdom values.

In addition, Minangkabau dance creation in present time is also able to act as a medium to implement the local wisdom values. This dance, although experiences modern change, still employs the custom and cultural rules of Minangkabau society. In line with this, through the dance creation has provenly able to draw the Minangkabau local wisdom values. In West Sumatera nowadays, art is employed as a medium to convey meanings related to local wisdom values. It can be inferred that the presence of Minangakabau dance creation brings impact to the preservation and continuation of Minangkabau local wisdom values both for present and future life.

In this study, researcher suggests the society of West Sumatera to keep preserving both traditional culture and dance creation side by side in order for the society to have media for local wisdom value delivery. Young generation is also suggested to raise the understanding of the importance of keeping art preservation continuation, especially dance. Dance here is considered to be an essential medium to be used as a medium for spreading the knowledge about local wisdom values besides also acted as an entertainment medium. Therefore, it is suggested for the involved society to realize the importance of dance preservation, both in traditional and creational manifestation which contains cultural meanings to build a nation character.

\section{REFERENCES}

Ardipal. (2015). Peran Partisipan sebagai Bagian Infrastruktur Seni di Sumatera Barat: Perkembangan Seni Musik Talempong Kreasi. Jurnal Resital, 16(1), 15-24.

Dewi, C. S. (2013). Representasi Kearifan Lokal Pada Lukisan Borobudur dan Bedaya Ketawang Karya Srihadi Soedarsono. Jurnal Ilmiah Widya, 1(1), 63-73.

Fauzul, A. (2014). Peranan Karya Seni dalam Pendidikan Karakter Mahasiswa Universitas Negeri Padang. Padang: FIS Universitas Negeri Padang.

Hanefi. (2011). Perubahan Pertunjukan Talempong Tradisional ke Pertunjukan Talempong Modern. Thesis. Padang: Pascasarjana Universitas Negeri Padang.

Indrayuda. (2007). Tari Minangkabau: Peran Elit Adat dan Keberlangsungan. Padang: Lemlit Universitas Negeri Padang.

Indrayuda. (2009). Peran Elit Adat dalam Keberlangsungan Tari Minangkabau. Jurnal Pendidikan dan Kebudayaan Balitbang Depdiknas Jakarta, 15(2).

Indrayuda. (2012). Cultural Development in Minangkabau Dance Through the Effect of social Politics in West Sumatera. Disertation. Universiti Sains Malaysia.

Irfi, S. W. (2015). Struktur Garapan Gandang Tambua Merupakan Perwujudan Kearifan Lokal Masyarakat Cubadak Aia Pariaman Utara. Thesis. Padang: Universitas Negeri Padang.

Murniati. (2015). Dekonstruksi Estetika dan Makna Musik Gamat di Sawahlunto, Sumatera Barat. Jurnal Resital, 16(1), 25-35.

Opsantini, R. D. (2014). Nilai-nilai Islami dalam Pertunjukan Tari Sufi pada Grup Kesenian Multikultural Kota Pekalongan. Jurnal Seni Tari, 3(1), 
1-13.

Rusliana, I. (2011). Kreativitas dalam Penyajian Tari Tradisi Sunda. Jurnal Panggung, 21(4).

Susmiarti. (2009). Fenomena Karya Tari Mahasiswa Sendratasik FBSS Universitas Negeri Padang. Padang: FBSS Universitas Negeri Padang.

Susmiarti. (2014). Model Pelestarian dan Pengembangan Tari Kain di Painan Timur: dari Tradisi Lokal ke Seni Hiburan. Reasearch Report. Padang: LEMLIT Universitas Negeri Padang.
Thomas, K. K. (2014). Revitalisation of the Performing Arts in the Ancestral Homeland of Lampung People, Sumatera. Wacana Seni Journal of Arts Discourse. 13, 29-55

Wadiyo, W. (2015). Music As An Integrated Education Tool for Preschool Students. Harmonia: Journal of Arts Research and Education, 15(2), 144-151.

Widiyono, Y. (2013). Nilai Pendidikan Karakter Tembang Campur Sari Karya Manthous. Jurnal Pendidikan Karakter, 2(2), 231-239. 